\title{
The Toillet in the Ears
}

\author{
Migzaid Diaz Barrios* \\ Otorrinolaringologo, Instituto Medico La Floresta, Venezuela
}

Submission: August 08, 2017; Published: August 11, 2017

*Corresponding author: Migzaid Diaz Barrios, Otorrinolaringologo, Instituto Medico La Floresta, Caracas, Venezuela, Tel: +584126555031

\section{Opinion}

Earwax is a yellowish substance secreted by the sebaceous and sweat glands of the skin of the outer third of the human ear, which plays an important role in the health of your outer ear. Among its functions are: CLEANING that is able to assist with the cleaning of dead cells of the whole external auditory canal outwards; A process known as epithelial migration, as well as dust and other debris. LUBRICATION of the skin of the ear canal as this prevents pruritus (itching) and peeling of the skin. BACTERICIDE has been scientifically proven to be capable of inhibiting bacterial and fungal growth. These are the reasons why earwax should not be removed using swabs and / or any other instruments for removal.

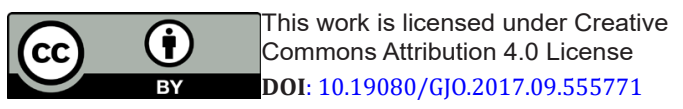

\section{But what do we recommend specialists?}

We recommend cleaning the ear cup when leaving the bathroom with a thin towel or a piece of toilet paper strictly on the outside to remove excesses. In cases where the accumulation of earwax occurs this may represent an impediment to your normal hearing, it is most advisable to go to your otolaryngologist who is the one who knows the best way to do the cleaning of ears. Do not use products such as hydrogen peroxide, alcohol, water, breast milk or others, as they are capable of generating infections inside the ear canal, making the picture worse. Also, we recommend that you consult your trusted specialist annually to perform your cleaning of ears and preferably 03 days before placing baby oil in each ear to facilitate easy removal of earwax and avoid formation of wax plugs.

\begin{tabular}{l} 
Your next submission with Juniper Publishers \\
will reach you the below assets \\
- Quality Editorial service \\
- Swift Peer Review \\
- Reprints availability \\
- E-prints Service \\
- Manuscript Podcast for convenient understanding \\
- Global attainment for your research \\
- Manuscript accessibility in different formats \\
( Pdf, E-pub, Full Text, Audio) \\
- Unceasing customer service \\
Track the below URL for one-step submission \\
https://juniperpublishers.com/online-submission.php \\
\hline
\end{tabular}

